\title{
Experimentation, "models" and the turn to practice
}

\author{
Isabelle F. Peschard and Bas C. Van Fraassen (Eds.): The experimental \\ side of modeling. University of Minnesota Press, 2018, 336pp, \$40 PB
}

\section{Guilherme Sanches de Oliveira ${ }^{1,2}$}

Published online: 8 September 2020

(c) The Author(s) 2020

The Experimental Side of Modeling, edited by Isabelle Peschard and Bas van Fraassen, is a diverse collection of thirteen chapters on model-based research and its relation to experimentation, theory, discovery, evidence, and other elements and aspects of science. The volume begins with an introduction by the editors in which they give an overview of the chapters and a substantial, if selective, account of the historical context unfolding since the early twentieth century and leading up to contemporary philosophical discussions about modeling. In the bulk of the book, nine essays by different authors engage with modeling in fields as varied as cognitive science, biology, economics, physics, and ecology, offering insights relevant not only for the philosophy of those specific sciences but also for broader metaphysical, epistemological and methodological discussions in general philosophy of science. In addition to the nine core essays, the book comes with a separate part, a symposium on measurement and realism, with four short chapters in which van Fraassen and Paul Teller engage with one another's views. Readers interested in these and related topics will find in the book ample information about recent developments in the different scientific disciplines covered and will also have a sample of key ideas that shape current philosophical thought on modeling. In what follows, I will not provide a chapter-bychapter summary of the views and arguments presented in the volume-the introductory chapter by Peschard and van Fraassen already does this well and, like the rest of the book, it is freely accessible online. Instead, I will take this opportunity to reflect on the volume as a whole, as framed by the editors, and as a window to the broader philosophy of science literature.

A first point to note is that the chapters in The Experimental Side of Modeling can be profitably approached as free-standing, self-contained contributions to philosophical discussions about modeling: most readers will be fine just picking and choosing

Guilherme Sanches de Oliveira

gui.cogsci@gmail.com

1 Department of Philosophy, Technische Universität Berlin, Berlin, Germany

2 Department of Psychology and Ergonomics, Technische Universität Berlin, Berlin, Germany 
which chapters to read, or in what order, according to what sparks their interest. Put in less of a positive light, this is because, with the exception of the chapters within the symposium, the essays have little explicit overlap between them in terms of background, definitions, focus, motivation and objectives. Yet this is neither particularly surprising nor necessarily a negative feature of the volume. This disunity and discontinuity is quite common in collections with multiple authors and, at least in this case, I do not think it is something for which to blame the editors. And this is because the disunity in question is a way in which the book succeeds in capturing the essence of the philosophical debate about modeling-namely that there is not a single "philosophical debate about modeling," but rather several disparate and narrowly circumscribed debates centering on different questions, operating under different assumptions, and focusing on different modeling contexts and disciplines. The editors acknowledge this, claiming that the essays reflect the philosophy of science literature "in their diversity of approach, in the tensions between them, and in the differences in focus that divide them" (52). Still, it is worth pondering what, if anything, the chapters have in common and, through that, considering the unity and disunity of the broader philosophy of science literature.

For Peschard and van Fraassen the big takeaway is that, despite their many differences, all chapters coincide in problematizing and reconceptualizing data. As they suggest, the different chapters converge in the realization that data, its nature and its role in science are far from straightforward, but demand further examination, and this is "the most striking, groundbreaking result perceivable in these contributions" (52). I agree with this sentiment-i.e., the concern with rethinking data-and I concede that it is at least to some extent expressed in each of the chapters. The same sentiment has been increasingly gaining traction in philosophy of science in recent years (see, e.g., Howlett and Morgan 2010; Leonelli 2016; Bokulich 2020), which further supports the claim that the volume is in tune with some of the main trends in the field.

But it is instructive to see how this reconceptualization of data is itself conceptualized, and how this conceptualization relates to different understandings of how philosophy of science is best done. Peschard and van Fraassen's account of the history of philosophical work on models begins with the usual suspects in early twentieth century philosophy of physics, logic and mathematics, and culminates in the turn to practice started in the 1980s and 90s which continues into the present. And it is in light of this historically situated turn to practice that Peschard and van Fraassen frame the concern with rethinking data. As they explain, turning to scientific practice reveals that data is not "a passive element of modeling or experimenting" but rather it is "both what need[s] to be produced and what need[s] to be accounted for to create the prospect for articulation of both the theoretical model and the model of the experiment" (52). So, the need to rethink our assumptions about data emerges because, on their view, the project of philosophically understanding scientific modeling amounts, on the one hand, to the project of philosophically elucidating theory (and, in the technical sense, identifying the "models of the theory," or more loosely, identifying possible interpretations of the theory) and, on the other hand, to the project of philosophically elucidating experimentation (and, in the technical sense, identifying the "model of the experiment," or more loosely the vision for the 
experimental setup or the benchmarking process scientists adopt). Uses of "model" such as these have deep historical roots in the philosophical literature, but it is not clear that they are what we need in practice-oriented philosophy of science. The categories Peschard and van Fraassen use such as "models of the data", "models of the theory" and "models of the experiment" do not seem to capture the sense of "model" at play in several domains of scientific practice, including nonlinear dynamical modeling in cognitive science (see Chapter 2 by Chemero), model organisms in biology (see Chapter 4, Knuuttila and Loettgers), and climate models (see Chapter 8 by Winsberg), to mention only examples that are discussed in the book.

So I agree with Peschard and van Fraassen that the need for reconsidering our understanding of data goes hand in hand with the turn to practice-the problem is that their justification for why this is the case is symptomatic of a turn to practice that remains, for many in our field, at best limited and reluctant. Many, perhaps most philosophers of science today would agree that we do not understand science properly if we ignore scientific practice, and moreover that, because practice never takes place in a void, we need to take into account the particular disciplinary contexts in which scientific research projects are situated. But few extend this situated understanding of scientific practice to an understanding of our own practice in philosophy of science. In this way, the turn to practice that philosophy of science has been undergoing, and for a good half century now, still lags far behind developments in cognate fields such as STS, where early on there was already a concern with reflexivity (see, e.g., Bloor 1976; Brown 1984). This persistent reluctance in our turn to practice is what allowed our field to spend so much time talking about theory-ladenness in science (a topic that appears several times throughout the volume) without seriously considering the theory-ladenness of our own analyses of science. If we recognize the importance of taking into account the particularities of scientific practice in different research situations, it is naive to think that we can do philosophy any differently than scientists can do their science. A good step in the right direction is to be critical of our philosophical baggage and, to the extent possible, try to understand science in its own terms rather than uncritically imposing our preconceived definitions and favored categories. Some chapters in the book do this well, such as the ones mentioned above by Chemero, Knuuttila and Loettgers, and Winsberg; others less so, and here I have to include the editors' introductory chapter. This tension between fully embracing the turn to practice, on the one hand, and joining it partially and reluctantly, on the other hand, pervades the book and is perhaps the more significant way the volume reflects tensions characteristic of philosophy of science today.

One final note concerns the format of the book. The presentation in the symposium part with van Fraassen and Teller is excellent, and their exchange is very helpful to clarify their views and give the reader a good sense of how they disagree and why. Reading it made me wish the rest of the book had been organized at least somewhat similarly, with some discussion being provided for each essay, even if just a brief commentary by one or more of the other contributors and a short response by the author. The essays in the book come from three workshops held at San Francisco University in 2009, 2010 and 2011, where presumably the participants questioned and responded to one another, and I think the book would have been an even 
richer resource if it presented the reader with a glimpse of those exchanges. This would have helped make the continuities between the different essays more evident, or maybe even helped forge those relations in the first place. Done well, this sort of effort could even contribute to increasing the continuity and unity that our field has so little of.

Funding Open Access funding provided by Projekt DEAL.

Open Access This article is licensed under a Creative Commons Attribution 4.0 International License, which permits use, sharing, adaptation, distribution and reproduction in any medium or format, as long as you give appropriate credit to the original author(s) and the source, provide a link to the Creative Commons licence, and indicate if changes were made. The images or other third party material in this article are included in the article's Creative Commons licence, unless indicated otherwise in a credit line to the material. If material is not included in the article's Creative Commons licence and your intended use is not permitted by statutory regulation or exceeds the permitted use, you will need to obtain permission directly from the copyright holder. To view a copy of this licence, visit http://creativecommons.org/licen ses/by/4.0/.

\section{References}

Bloor, David. 1976. Knowledge and social imagery. Chicago: University of Chicago Press.

Bokulich, A. 2020. Towards a taxonomy of the model-ladenness of data. Philosophy of Science. https:// doi.org/10.1086/710516.

Brown, James Robert. 1984. Scientific rationality: The sociological turn. Berlin: Springer.

Howlett, P., and M.S. Morgan (eds.). 2010. How well do facts travel? The dissemination of reliable knowledge. Cambridge: Cambridge University Press.

Leonelli, S. 2016. Data-centric biology: A philosophical study. Chicago: University of Chicago Press.

Publisher's Note Springer Nature remains neutral with regard to jurisdictional claims in published maps and institutional affiliations. 